\title{
Soundscape of protected and unprotected tropical Atlantic coastal coral reefs
}

\author{
Alfredo Borie ${ }^{1,5}$, Sergio Magalhães Rezende ${ }^{2}$, Beatrice Padovani Ferreira ${ }^{3}$, Mauro Maida ${ }^{3}$, \\ Craig Radford ${ }^{4}$, Paulo Travassos ${ }^{5}$ \\ ${ }^{1}$ Departamento de Engenharia de Pesca, Universidade Federal de Alagoas, Av. Beira Rio, s/n -Centro, Penedo- AL, 57200-000 \\ (AB) (Corresponding author) E-mail: a.borie@gmail.com. ORCID iD: https://orcid.org/0000-0002-1044-9421 \\ ${ }^{2}$ Centro de Pesquisa e Conservação da Biodiversidade Marinha do Nordeste, Rua Samuel Hardman s/n, Tamandaré, \\ CEP 55.578-000 \\ (SMR) E-mail: rezende.sergiomagalhaes@gmail.com. ORCID iD: https://orcid.org/0000-0001-9050-6475 \\ ${ }^{3}$ Departamento de Oceanografia, Universidade Federal de Pernambuco \\ (BPF) E-mail: beatricepadovaniferreira@gmail.com. ORCID iD: https://orcid.org/0000-0001-6315-9834 \\ (MM) E-mail: maida.mauro@yahoo.com. ORCID iD: https://orcid.org/0000-0002-1136-8631 \\ ${ }^{4}$ Institute of Marine Science, Leigh Marine Laboratory, Institute of Marine Science, University of Auckland, New Zealand \\ (CR) E-mail: c.radford@ auckland.ac.nz. ORCID iD: https://orcid.org/0000-0001-7949-9497 \\ ${ }^{5}$ Departamento de Pesca e Aquicultura, Universidade Federal Rural de Pernambuco CEP 52.171-900, Recife, PE, Brasil. \\ (PT) E-mail: pautrax@ hotmail.com. ORCID iD: https://orcid.org/0000-0001-8667-5292
}

\begin{abstract}
Summary: Behavioural patterns and distributions of crustaceans, fish and mammals can be inferred from acoustic recordings of the extremely noisy marine acoustic environment. In this study, we determined the soundscape of protected and non-protected marine areas between January and April 2016. Sonobuoy (a device for sound monitoring) recordings began at sunset and lasted approximately 12 hours per day. The results show a complex soundscape dominated by biological sounds produced by crustaceans and fish. Six fish chorus-dominant frequencies between 200 and $1000 \mathrm{~Hz}$ occurred at a similar time each day, except for chorus I. The choruses consisted of high-energy callings after the last reef line within the protected area. However, fish choruses showed low energy levels in unprotected areas. The results show the importance of protected areas for fish populations and the usefulness of passive acoustics to monitor biodiversity of sounds of commercial fish in Brazilian tropical costal reefs.
\end{abstract}

Keywords: passive acoustic; bioacoustics; marine cacophony; fish and crustacean sounds.

Paisaje acústico de arrecifes de coral costeros protegidos y desprotegidos del Atlántico tropical

Resumen: Los patrones de comportamiento y la distribución de crustáceos, peces y mamíferos pueden inferirse a partir de grabaciones acústicas del ambiente acústico marino extremadamente ruidoso. En este estudio, determinamos el paisaje sonoro de áreas marinas protegidas (AMP) y no protegidas entre enero y abril de 2016. Las grabaciones de "sonoboyas" (un dispositivo para monitoreo de sonido) comenzaron al atardecer y duraron aproximadamente 12 horas por día. Los resultados muestran un paisaje acústico complejo dominado por sonidos biológicos producidos por crustáceos y peces. Se encontraron seis frecuencias dominantes de coros de peces entre 200 y $1000 \mathrm{~Hz}$, encontrados a la misma hora todos los días, excepto el coro I. Los coros consistían en llamadas de alta energía después de la última línea de arrecife dentro del área protegida. Sin embargo, los coros de pescado presentaron niveles de energía bajos en áreas desprotegidas. Los resultados muestran la importancia de las áreas protegidas para las poblaciones de peces y la utilidad de la acústica pasiva para monitorear la biodiversidad de los sonidos de los peces comerciales en los arrecifes costeros tropicales brasileños.

Palabras clave: acústica pasiva; bioacústica; cacofonía marina; sonidos de peces y crustáceos.

Citation/Como citar este artículo: Borie A., Rezende S., Padovani B., Maida M., Radford C., Travassos P. 2021. Soundscape of protected and unprotected tropical Atlantic coastal coral reefs. Sci. Mar. 85(1): 5-14. https://doi.org/10.3989/ scimar.05052.001

Editor: V.D. Valavanis.

Received: March 18, 2020. Accepted: October 18, 2020. Published: March 31, 2021.

Copyright: ( $\odot 2021$ CSIC. This is an open-access article distributed under the terms of the Creative Commons Attribution 4.0 International (CC BY 4.0) License. 


\section{INTRODUCTION}

In recent years, soundscapes have been used to evaluate marine and terrestrial environments in order to understand several biotic and abiotic relationships better (Pijanowski et al. 2011). Although it is generally difficult to acoustically assess the marine environment, recent technological advances in equipment and acoustic analysis software have contributed to the knowledge of marine soundscapes and sounds associated with social interactions of different groups of marine organisms (Lammers et al. 2008).

Marine soundscapes are composed of three components: The first component consists of biotic sounds made by the animals themselves, such as fish (Amorim et al. 2006), shrimps (Lammers and Munger 2016), bivalves (Coquereau et al. 2016, Lillis et al. 2016), crabs (Boon et al. 2009), lobsters (Buscaino et al. 2011), sea urchins (Radford et al. 2008) and marine mammals (Frankel 2009). They are associated with several behaviours. The second component is abiotic sounds produced by natural events, such as wind and waves (geophonic). The third component is anthropogenic sounds, such as those of ships.

The soundscape of coastal reefs is important because it is as an orientation for fish larval settlement (Simpson et al. 2004, Radford et al. 2011), crustaceans (Montgomery et al. 2006), molluscs (Lillis et al. 2015, Egglestone et al. 2016) and reef-building corals (Lillis et al. 2016, 2018).

Passive acoustic monitoring (PAM) is a non-invasive and non-destructive observation tool. It has a permanent or long-term remote monitoring capability, providing important information on daily and seasonal patterns (Rountree et al. 2006). Furthermore, PAM can be used as a complementary tool to assess habitat quality and health of ecosystems (Piercy et al. 2014, Harris et al. 2016) and to monitor biodiversity (Kaplan et al. 2015).

Marine protected areas are an effective method for protecting marine biodiversity and habitats. Protected areas of coral reefs, when efficiently and effectively managed, are expected to sustain a high biological diversity and a soundscape composed mainly of biological sounds (Bertucci et al. 2016). Although soundscape studies have been conducted on temperate waters of the South American Atlantic (Sánchez-Gendriz and Padovese 2016, 2017), there are no studies on equatorial Atlantic coastal reef areas. Therefore, the aim of this work was to investigate soundscapes of protected and unprotected Brazilian equatorial coastal reef areas to provide baseline information for future long-term soundscape monitoring programmes that aim to provide information for conservation actions.

\section{MATERIALS AND METHODS}

\section{Study area}

This study was conducted in two coastal reef locations: Tamandaré (a marine protected area) and Porto de Galinhas, Pernambuco state, northeastern Brazil (Fig. $1)$. The areas are part of the northeastern coral reef sys-
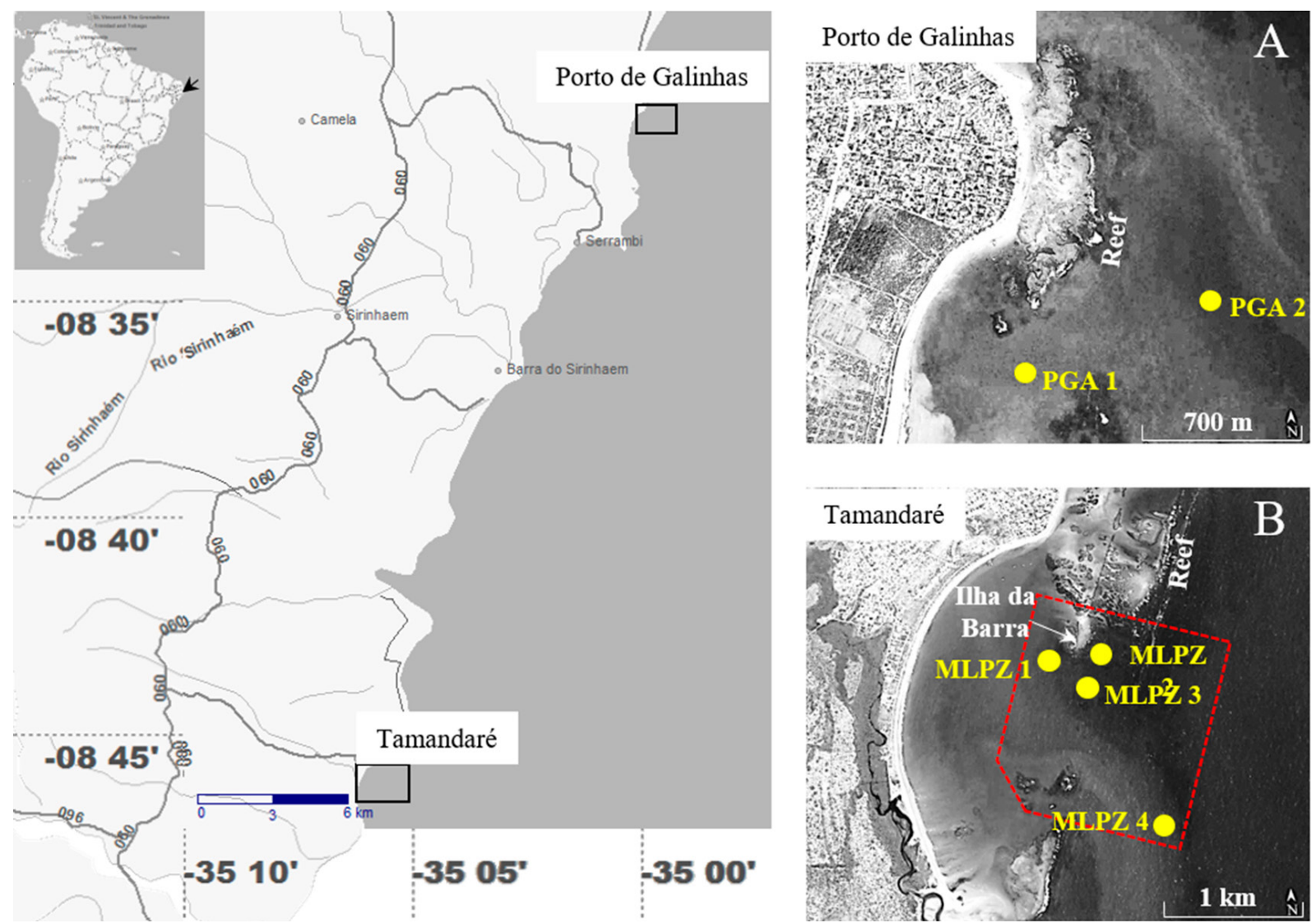

Fig. 1. - Map of study areas. Locations of sonobuoys used in Porto de Galinhas (A) and Tamandaré (B) and reef proximity in both locations. The red dashed line represents the limits of the Marine Life Preservation Zone in Tamandaré (MLPZ). 
tem, which is characterized by reef lines parallel to the coast (Rodríguez-Ramírez et al. 2008). The areas consist of elongated and discontinuous reefs with dimensions varying from less of $1 \mathrm{~km}$ in length to about $4 \mathrm{~km}$, in reefs close to the beach (Dominguez et al. 2018). There are typically three reef lines: one near the beach, then a second line, and a third line exposed to the open sea (Ferreira and Maida 2006).

Both areas are popular tourist destinations. Porto de Galinhas, close to Recife $(60 \mathrm{~km})$, is one of the most visited beaches in Brazil. Uncontrolled tourism has caused environmental impacts due to trampling, waste deposition and fish feeding (Barradas et al. 2012, 2010). Although both areas are within the same reef system, their management is different. Porto de Galinhas has no protection, whereas Tamandare is part of the largest Brazilian coastal conservation unit, the Costa dos Corais Marine Protected Area (CCMPA), created in 1997. Located inside the CCMPA, Tamandare is within the Marine Life Preservation Zone (MLPZ). It has been closed to fishing and tourism since 1999 (Ferreira and Maida 2006). The fish community in Tamandaré is diverse and comprises estuarine, reef-associated, and pelagic species (Ferreira and Cava 2001).

\section{Soundscape recordings}

The soundscape was measured using a custom-made sonobuoy (Fig. 2) equipped with a calibrated omnidirectional hydrophone (H2A, Aquarian Audio, Anacortes, WA, USA, useful range $10 \mathrm{~Hz}$ to 100 $\mathrm{kHz}$, sensitivity of $-180 \mathrm{~dB}$ re $1 \mathrm{~V} / \mu \mathrm{Pa}$, flat frequency response $\pm 4 \mathrm{~dB}$ within the range $20 \mathrm{~Hz}$ to $4.5 \mathrm{kHz}$ ). The sonobuoy was built using low-cost materials and consists of a 20-mm diameter, 2.5-m long PVC pipe. It is connected to a Panasonic RR-XS450 digital recorder (16-bit WAV format and sampling rate of $44 \mathrm{kHz}$ ). A weight was fixed at the lower end of the pipe, and a buoy was installed for flotation. A PVC box of 1000 $\mathrm{cm}^{3}$ located at the upper end (1.5 $\mathrm{m}$ out of the water) housed the digital recorder (Fig. 2).

Each sonobuoy was installed at three sites in the MLPZ (MLPZ 1, 2 and 3) near the reef called Ilha da Barra in the bay of Tamandaré (Fig. 1) during non-consecutive days in January 2016. Recordings began at the end of the morning. Recordings lasted 20, 23 and 13 hours at each site, respectively.

Two sonobuoys were used simultaneously to evaluate the acoustic signals at two stations in Tamandaré (MLPZ 3 and MLPZ 4) and at two stations in Porto de Galinhas (PGA 1 and PGA 2) between February and April 2016. Recordings were performed simultaneously at both sites of each location. They began at sunset and ended at dawn. During the summer, the sunset takes place at approximately 5:30 p.m. and the sunrise at 5:20 a.m. The duration of day and night is almost the same.

The sonobuoys were positioned 6-8 $\mathrm{m}$ deep near the reef and 14-16 $\mathrm{m}$ beyond the last reef line. The hydrophone was submerged $6 \mathrm{~m}$ from the surface. The buoys were installed about $1200 \mathrm{~m}$ apart, 1.4 and $2 \mathrm{~km}$ from the beach line in Tamandaré bay (Fig. 1). Recordings in

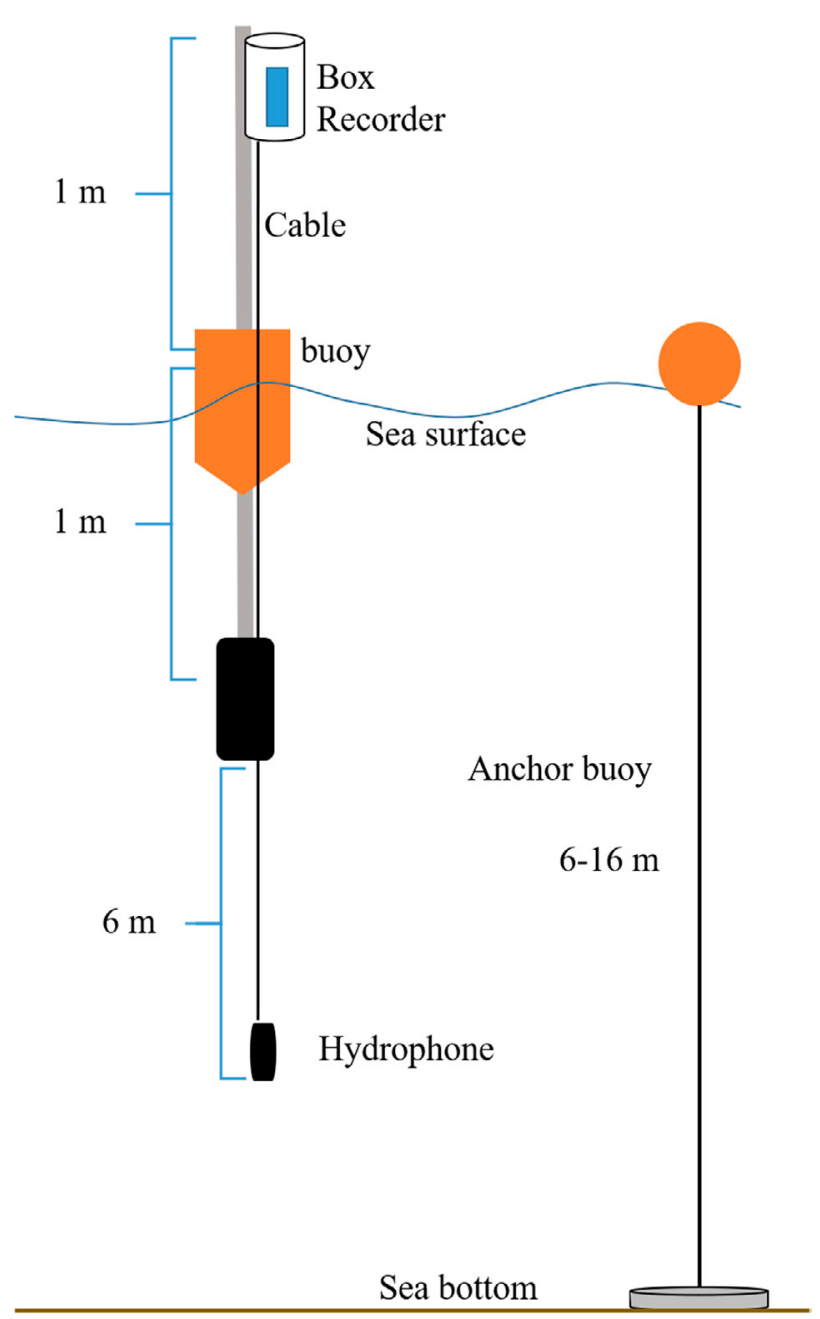

Fig. 2. - Configuration of the sonobuoy used in Tamandaré and Porto de Galinhas.

Porto de Galinhas were performed in relatively equivalent areas located before the last reef line (PGA 1) and beyond the last reef line (PGA 2). They were about $800 \mathrm{~m}$ apart and $600 \mathrm{~m}$ and $1200 \mathrm{~m}$ from the coast, respectively.

\section{Acoustic data analyses}

286 hours of recordings were analysed: 180 hours from Tamandaré and 106 hours from Porto de Galinhas. The files were downloaded to a portable computer. A pre-evaluation was performed using the Audacity ${ }^{\circledR}$ software (v. 2.2). Audacity ${ }^{\circledR}$ was also used to select interesting parts of the recordings for in-depth analysis.

To evaluate the frequency bandwidth distribution over time and the energy of the coastal reef soundscape, spectrograms and power spectral density (PSD) were plotted using the PAMGuide toolbox (Merchant et al. 2015) of MATLAB 2016. The spectrograms and PSD were initially plotted with a frequency bandwidth of between 50 and $10000 \mathrm{~Hz}$ (pre-analyses). A bandwidth of between 50 and $5000 \mathrm{~Hz}$ was used for analysis. The root mean square of PSD values was calculated for all days of recording at each point. 
To perform the individual analysis of each acoustic signature ("call"), the Raven Pro software 1.4 (Cornell Laboratory of Ornithology) was used. Five-minute sections of each sound recording were used for individual characterization of each call (acoustic unit). The sections were chosen according to quality and energy. The aim was to select parts without signal overlaps whenever possible. The selected parts were band-pass filtered using the frequency bandwidth used in the spectrograms. The signals were characterized using the following parameters: 1) number of pulses/call (n), 2) call duration (time between first and last pulse, ms), 3) pulse rate (n pulses/second), 4) pulse period (time between the peaks of second and third pulses), 5) low-frequency limit $(\mathrm{Hz}), 6)$ high-frequency limit $(\mathrm{Hz})$, 7) central frequency $(\mathrm{Hz})$, and 8) dominant frequency $(\mathrm{Hz})$. The description of the latter two parameters was obtained using the method of Charif et al. (2010). The acoustic parameters were measured using oscillograms and spectrograms, a fast Fourier transform size of 1024 , and $99 \%$ overlap. Acoustic parameters of sounds were compared using a non-parametric Kruskal-Wallis multiple comparison test for each variable $(\mathrm{P}<0.05)$ in the STATISTICA 7 software (Dell Inc.).

\section{RESULTS}

\section{Soundscape and fish chorus recordings}

In general, the soundscape was dominated by snapping shrimps and various species of fish around the Ilha da Barra reef in Tamandaré (Fig. 3). The frequency of these sounds was lower than $4 \mathrm{kHz}$. The acoustic signals were partitioned by time. The snapping sounds showed frequencies of between 2 and $3 \mathrm{kHz}$, which occurred at higher densities during sunset and dawn. Fish choruses showed frequencies of between 200 and 1800 $\mathrm{Hz}$. We identified six different types of chorus.

Chorus I around the Ilha da Barra reef was a tonal signal with harmonics within the $400-2000 \mathrm{~Hz}$ frequency band. Chorus II slightly overlapped with Chorus $I$ in the frequency band of $1600-1800 \mathrm{~Hz}$ with no harmonics (Fig. 3A). It was produced after midnight. Chorus III had a frequency bandwidth of $200-800 \mathrm{~Hz}$ and occurred just before sunset and after midnight. In this area, the sound of snapping shrimps dominated the soundscape. Choruses I, II and III showed low amplitude levels (Fig. 3B). A little further away from the Ilha da Barra (MLPZ 3), despite a shorter recording time, three other types of fish chorus were detected: Chorus IV at a frequency band of $800-3500 \mathrm{~Hz}$, Chorus V $(150-900 \mathrm{~Hz})$ and Chorus VI $(80-300 \mathrm{~Hz})$. These signals occurred at the beginning of the night and overlapped temporally. The snapping sound and Chorus III were not evident in MLPZ 3 (Fig. 3C). PSD analyses indicated high acoustic levels in MLPZ 3, as well as Chorus I peaks in a dominant frequency of approximately $900 \mathrm{~Hz}$, but with a wide frequency band overlapping and masking other signals (Fig. 4).

Chorus I occurred more often than the other choruses in Tamandaré and Porto de Galinhas (Fig. 5). The coastal soundscape of Tamandaré (MLPZ 3 and MLPZ

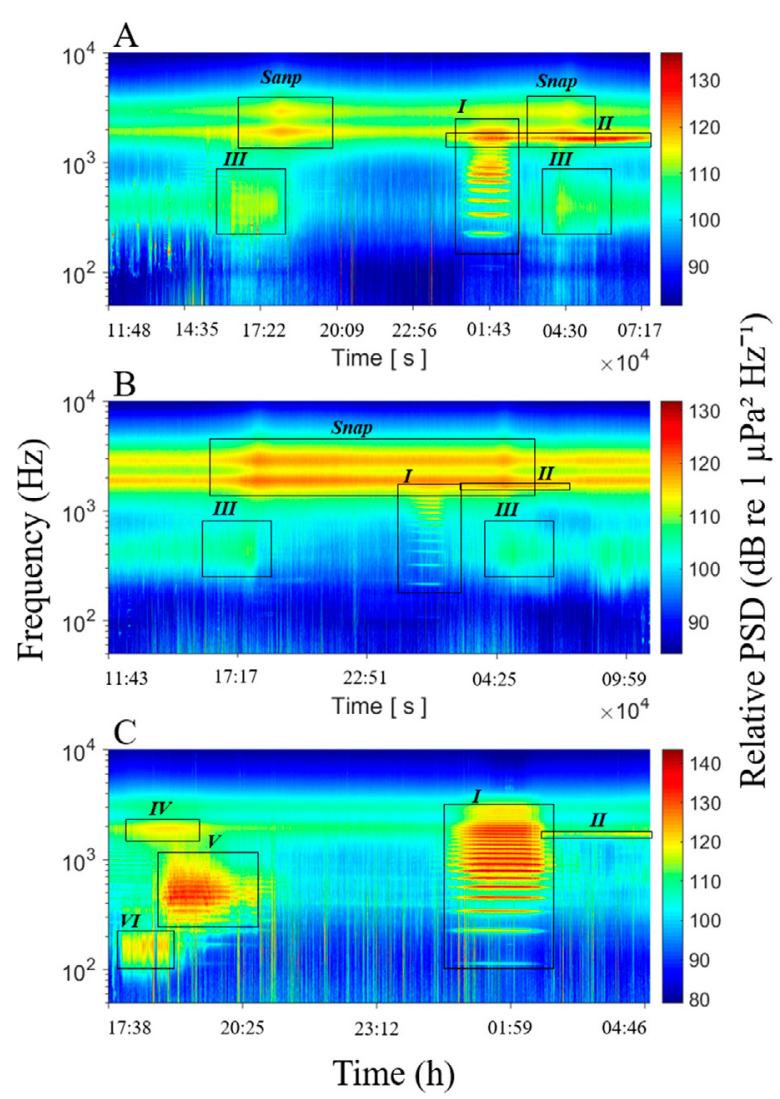

Fig. 3. - Spectrograms (sonograms) showing time variation of frequency and power spectral density (PSD) of recordings near the Ilha da Barra reef in Tamandaré. A, MLPZ 1 (Jan 24), B, MLPZ 2 (Jan 26) and C, MLPZ 3 (Feb 4), marking the main acoustic signals. "Snap" corresponds to crustacean sounds. Choruses I, II, III, IV, V and VI are fish sounds.

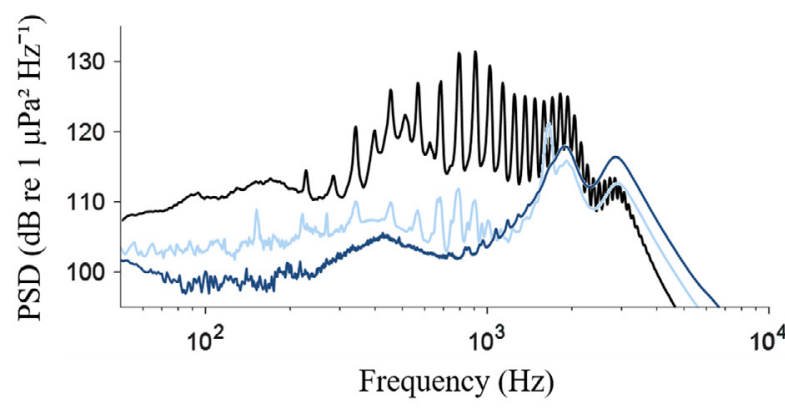

Fig. 4. - Average power spectrum (spectra) highlighting the frequency $(\log )$ components that occur continually in recordings around the Ilha da Barra reef. MLPZ 1 Jan 24 (light blue line), MLPZ 2 Jan 26 (blue line), and MLPZ 3 Feb 04 at night (black line). The peaks of dominant frequency correspond to Chorus I ( $\sim 900 \mathrm{~Hz}$, black line), Chorus II $(\sim 1700 \mathrm{~Hz}$, light blue line) and Chorus IV $(\sim 1800 \mathrm{~Hz}$, blue line $)$. Broad frequency bandwidth mask the other signals.

4) and Porto de Galinhas (PGA 1 and PGA 2) consisted of sounds during sunset and late night. Furthermore, fish choruses previously found were better detected at the furthest site in Tamandaré (MLPZ 4).

In Porto de Galinhas, there were low energy levels of Chorus V and Chorus VI, as well as a sound similar to rapping (termed "Rap") at the beginning of the night (Fig. 5C, D) in areas near the second reef line (PGA 

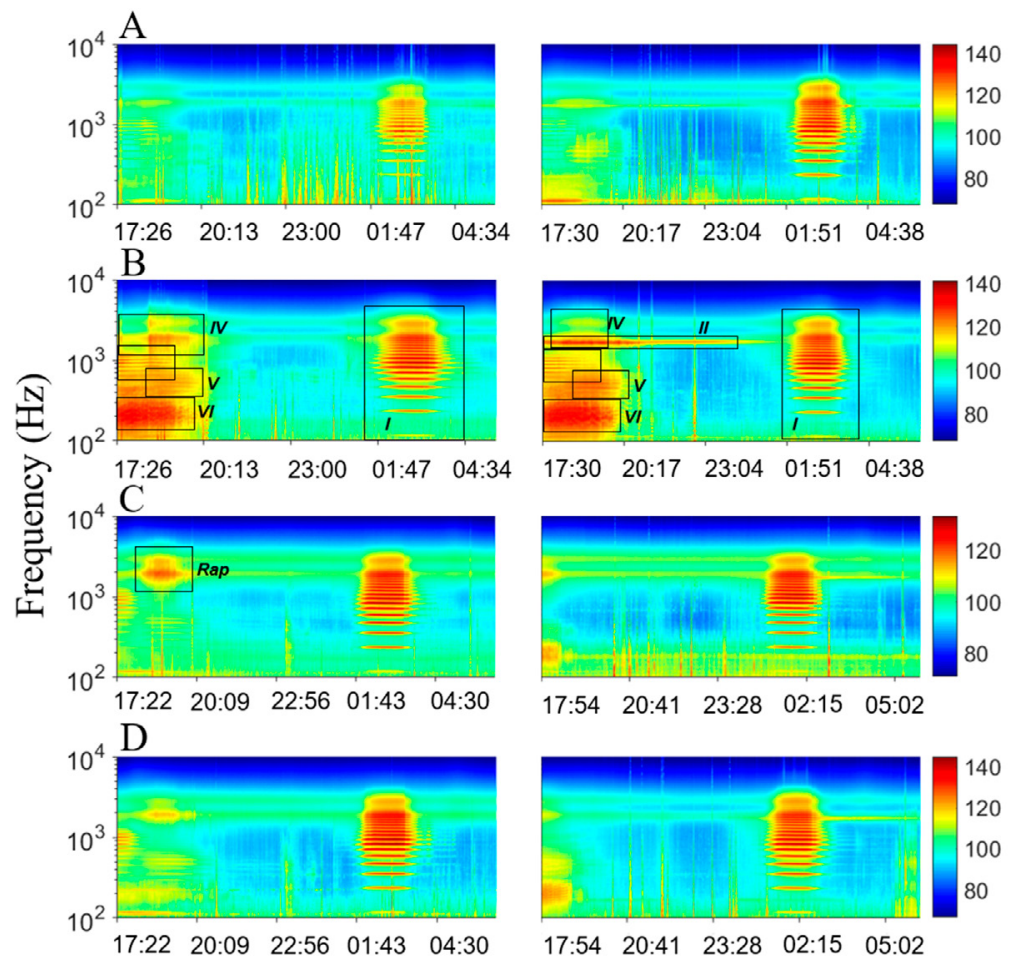

굴

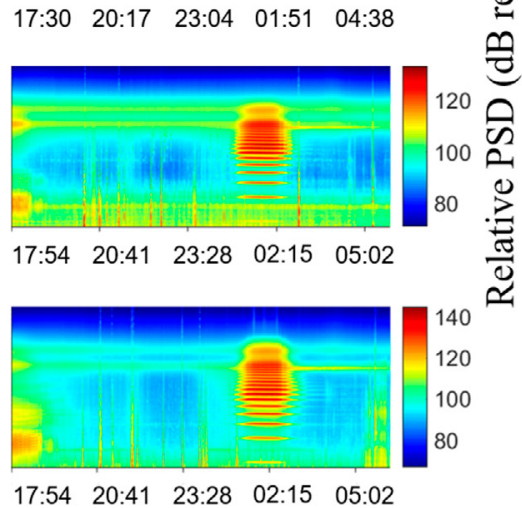

Time (h)

Fig. 5. - Spectrograms showing time variation of frequency and power spectral density (PSD) of recordings made between $\sim 5: 30 \mathrm{pm}$ and 5:30 am in Tamandare and Porto de Galinhas in March. A, MLPZ 3; B, MLPZ 4; C, PGA 1; D, PGA 2, highlighting the main acoustic signals. Choruses I, II, IV, V, and VI are fish sounds (overlapping during the sunset) and "Rap" is crustacean sounds.

1). The Rap sound had characteristics similar as those of the snapping shrimp sound, with dominant frequencies at $\sim 2000$ and $2400 \mathrm{~Hz}$, respectively (Table 1). This sound was also recorded near the Ilha da Barra reef in Tamandaré (Fig. 6).

The MLPZ 4 had high acoustic levels for Chorus I, Chorus V, and Chorus VI before sunset (Fig. 7A). Chorus I, detected after midnight, showed a similar acoustic energy at the four stations sampled (Fig. 7B).

\section{Fish call analyses}

Fish calls were comprised sets of pulse trains with different acoustic characteristics (acoustic signatures). The pulses contained one cycle, several cycles as occurred in Chorus V (Fig. 8A), Chorus III (Fig. 8E), and Chorus II (Fig. 8F), or paired pulses as occurred
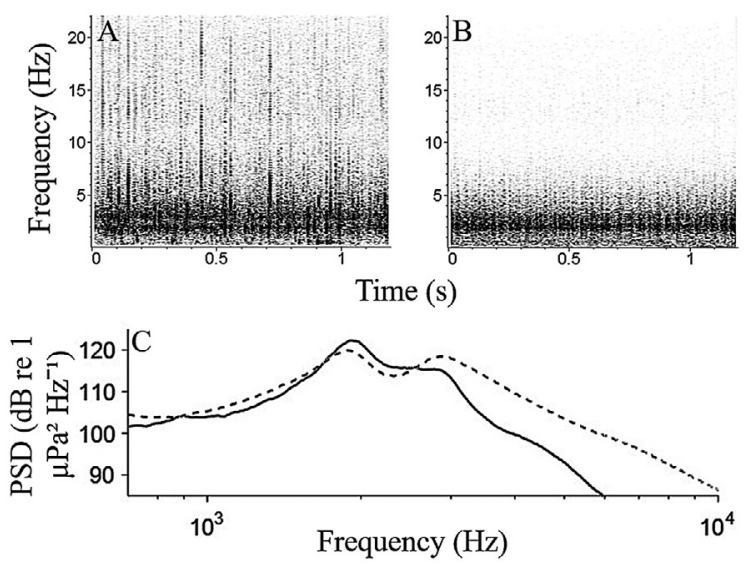

Fig. 6. - Spectrograms of crustacean sounds. A, "Snap"; B, "Rap" (recorded in Porto de Galinhas); and C, power spectrum of "Snap" frequency (black line) and "Rap" frequency (blue line).

Table 1. - Acoustic parameters of crustacean sound pulses detected in Porto de Galinhas. Different letters on the same line represent significant differences by Kruskal-Wallis non-parametric test and multiple comparisons of $\mathrm{P}$ values: $\mathrm{H}(1, \mathrm{~N}=261)$.

\begin{tabular}{ccccc}
\hline Sound type & $\begin{array}{c}\text { Dominant } \\
\text { frequency }(\mathrm{Hz})\end{array}$ & $\begin{array}{c}\text { Low frequency } \\
(\mathrm{Hz})\end{array}$ & $\begin{array}{c}\text { High frequency } \\
(\mathrm{Hz})\end{array}$ & $\begin{array}{c}\text { Pulse duration } \\
(\mathrm{ms})\end{array}$ \\
\hline Snap & $2413 \pm 564^{\mathrm{a}}$ & $1771 \pm 416^{\mathrm{a}}$ & $3192 \pm 579^{\mathrm{a}}$ & $2.3 \pm 1.2^{\mathrm{a}}$ \\
$(\mathrm{n}=81)$ & $(1637-3618)$ & $(1093-2876)$ & $(1997-4057)$ & $(1.0-7.0)$ \\
& & & $3000 \pm 450^{\mathrm{b}}$ & $3.4 \pm 2.1^{\mathrm{b}}$ \\
$(\mathrm{n}=180)$ & $2071 \pm 319^{\mathrm{b}}$ & $1532 \pm 276^{\mathrm{a}}$ & $(2118-4727)$ & $(1.0-17.0)$ \\
\hline
\end{tabular}




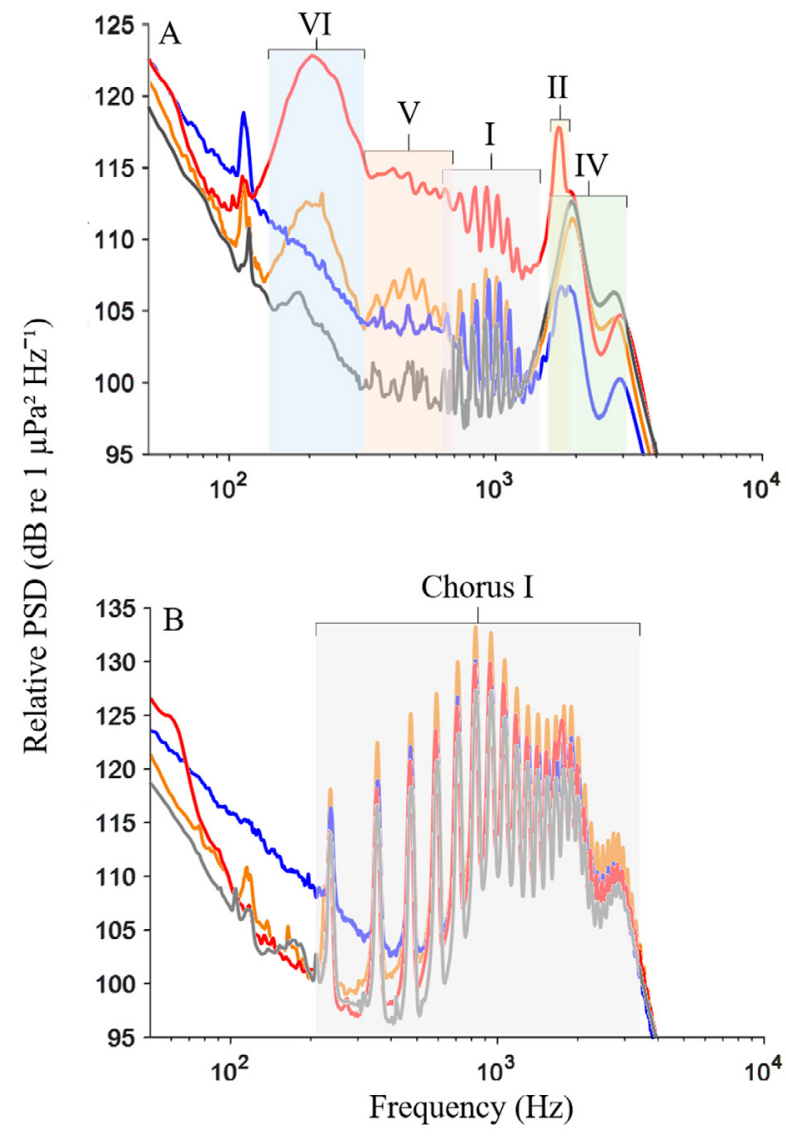

Fig. 7. - Power Spectral Density highlighting the frequency $(\log )$ components that occur continually in the recordings $\mathrm{A}$, at night (between $\sim 5: 30$ p.m. and midnight) and B, after midnight (00:00 a.m. to 5:00 am). Different peaks of dominant frequency of fish choruses in MLPZ 3 (blue), MLPZ 4 (red), PGA 1 (grey), and PGA 2 (orange).
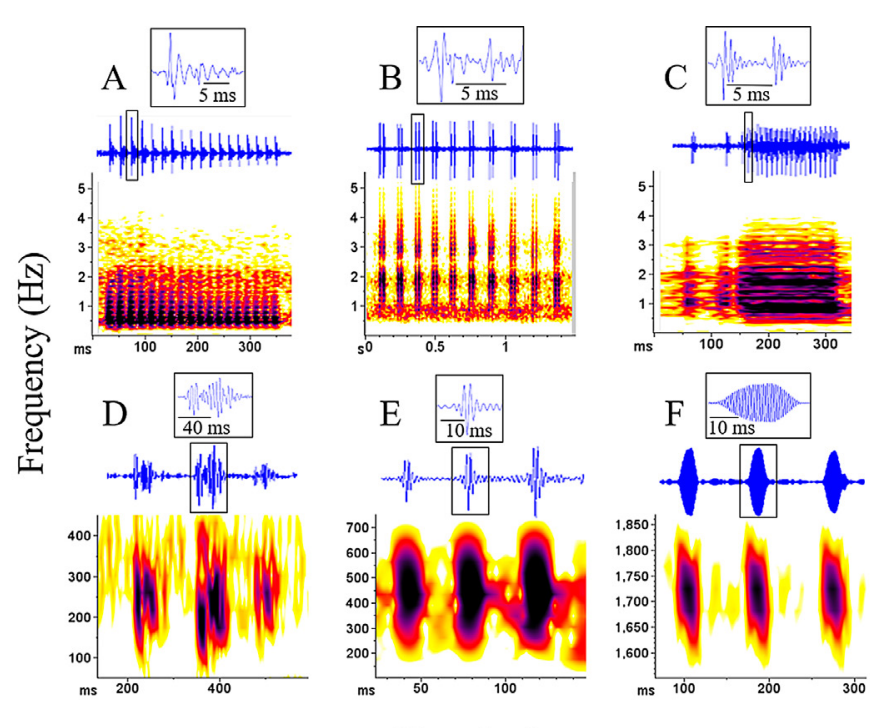

Time (ms)

Fig. 8. - Oscillograms (waveforms), spectrograms of individual calls (below), and respective magnified pulse (quadrants). Track of pulses in A, "Chorus V"; B, "Chorus IV" (paired); C, "Chorus I" (paired); D, "Chorus VI"; E, "Chorus III"; F, "Chorus II". In the figure, change "Number of pulse" to "Number of pulses". in Chorus I (Fig. 8B), Chorus IV (Fig. 8C) and Chorus VI (Fig. 8D).

The calls were composed of three to 39 pulses depending on the type of call. Calls with three pulses were found in Choruses II, III and VI. The calls of Chorus I had the highest number of pulses per call (mean of 25.1), followed by Chorus V (mean of 19.3) (Table 2).

The dominant frequencies were 204, 570, 925 and $1838 \mathrm{~Hz}$ for Choruses VI, V, I and IV, respectively. Although there was a frequency overlap between Chorus IV and Chorus II sounds, and their values did not differ significantly, they may be related to pulse rate since this value also showed no differences. Nevertheless, these sounds have a different frequency band (low and high), pulse period, number of pulses and consequently call duration (Table 2). Chorus $\mathrm{V}$ and Chorus VI sounds showed similar frequencies. All acoustic parameters indicated a significant difference between the two sounds $(\mathrm{p}<0.05)$. Though the dominant frequency values between Choruses III and VI showed no differences, they did not occur at the same location $(\mathrm{P}>0.05)$.
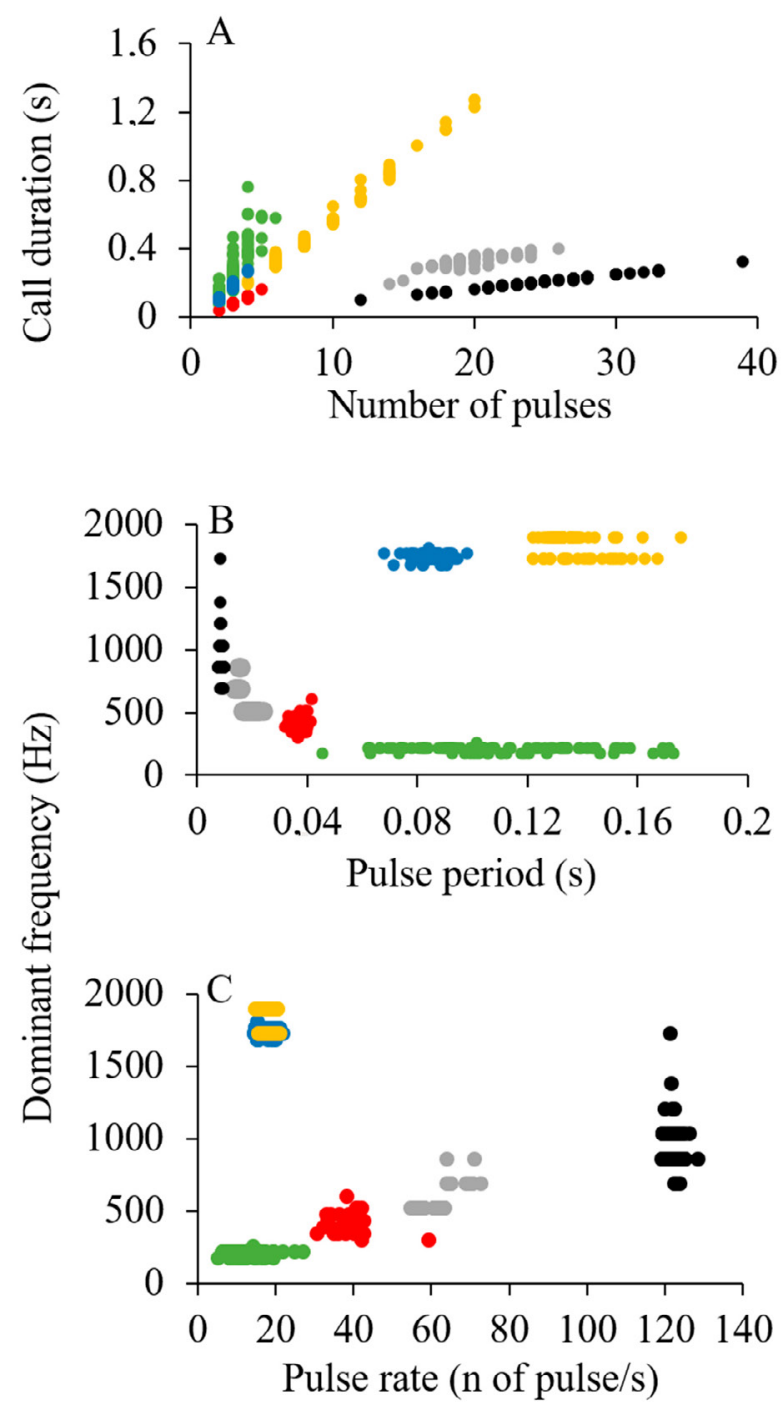

Fig. 9. - Relation between call duration. A, number of pulses in individual calls and dominant frequency $(\mathrm{kHz}) ; \mathrm{B}$, pulse rate (pulses per second); C, pulse period (ms). Choruses I (black), II (yellow), III (red), IV (blue), V (grey) and VI (green). 
Table 2. - Acoustic parameters of fish choruses found in Tamandaré. Mean \pm standard deviation (minimum-maximum). Different letters on the same line represent significant differences by Kruskal-Wallis non-parametric test and multiple comparison $\mathrm{P}$ values: $\mathrm{H}(5, \mathrm{~N}=430)$.

\begin{tabular}{|c|c|c|c|c|c|c|}
\hline $\begin{array}{l}\text { Acoustic } \\
\text { parameter }\end{array}$ & $\begin{array}{l}\text { Chorus I } \\
(n=84)\end{array}$ & $\begin{array}{l}\text { Chorus II } \\
(\mathrm{n}=90)\end{array}$ & $\begin{array}{l}\text { Chorus III } \\
\quad(n=30)\end{array}$ & $\begin{array}{l}\text { Chorus IV } \\
(n=72)\end{array}$ & $\begin{array}{l}\text { Chorus V } \\
(n=64)\end{array}$ & $\begin{array}{l}\text { Chorus VI } \\
\quad(n=90)\end{array}$ \\
\hline No. of pulses/ call & $\begin{array}{c}25.1 \pm 4.6 \mathrm{c} \\
(12.0-39.0)\end{array}$ & $\begin{array}{l}2.7 \pm 0.5 \mathrm{a} \\
(2.0-4.0)\end{array}$ & $\begin{array}{l}3.4 \pm 0.6 \mathrm{ab} \\
(2.0-5.0)\end{array}$ & $\begin{array}{c}9.7 \pm 3.8 \mathrm{~d} \\
(4.0-20.0)\end{array}$ & $\begin{array}{c}19.3 \pm 2.3 \mathrm{c} \\
(14.0-26.0)\end{array}$ & $\begin{array}{l}3.1 \pm 0.9 \mathrm{ab} \\
(2.0-6.0)\end{array}$ \\
\hline Call duration (ms) & $\begin{array}{l}205.1 \pm 38.4 a \\
(97.4-320.5)\end{array}$ & $\begin{array}{l}163.3 \pm 43.2 \mathrm{c} \\
(90.8-276.2)\end{array}$ & $\begin{array}{c}90.2 \pm 25.9 \mathrm{e} \\
(33.7-162.8)\end{array}$ & $\begin{array}{c}556.6 \pm 253.2 b \\
(189.8-1273.0)\end{array}$ & $\begin{array}{c}322.5 \pm 35.2 \mathrm{~d} \\
(192.5-400.6)\end{array}$ & $\begin{array}{c}283.9 \pm 138.9 a \\
(73.7-758.9)\end{array}$ \\
\hline Pulse rate & $\begin{array}{c}122.4 \pm 1.8 \mathrm{c} \\
(119.3-128.5)\end{array}$ & $\begin{array}{c}17.1 \pm 1.9 \mathrm{a} \\
(14.5-22.0)\end{array}$ & $\begin{array}{l}38.3 \pm 3.8 b \\
(5.3-27.2)\end{array}$ & $\begin{array}{c}17.8 \pm 1.3 \mathrm{a} \\
(14.9-21.1)\end{array}$ & $\begin{array}{c}59.9 \pm 4.5 b \\
(54.7-72.7)\end{array}$ & $\begin{array}{l}12.3 \pm 3.8 \mathrm{~d} \\
(5.3-27.2)\end{array}$ \\
\hline Pulse period (ms) & $\begin{array}{l}8.7 \pm 0.4 b \\
(7.7-9.9)\end{array}$ & $\begin{array}{c}84.2 \pm 4.9 \mathrm{~d} \\
(68.1-98.2)\end{array}$ & $\begin{array}{c}37.1 \pm 2.4 \mathrm{a} \\
(31.9-41.6)\end{array}$ & $\begin{array}{c}136.6 \pm 11.1 \mathrm{c} \\
(122.0-175.7)\end{array}$ & $\begin{array}{c}19.1 \pm 2.6 \mathrm{a} \\
(13.5-24.0)\end{array}$ & $\begin{array}{l}111.6 \pm 34.3 \mathrm{e} \\
(45.5-210.9)\end{array}$ \\
\hline Low frequency $(\mathrm{Hz})$ & $\begin{array}{c}375.5 \pm 124.2 b \\
(120.4-658.4)\end{array}$ & $\begin{array}{c}1623.0 \pm 36.5 \mathrm{~d} \\
(1554.6-1712.6)\end{array}$ & $\begin{array}{l}207.8 \pm 44.5 \mathrm{ab} \\
(134.7-373.6)\end{array}$ & $\begin{array}{c}859.8 \pm 229.3 \mathrm{c} \\
(372.5-1478.9)\end{array}$ & $\begin{array}{c}169.9 \pm 62.6 \mathrm{a} \\
(105.1-354.3)\end{array}$ & $\begin{array}{c}83.2 \pm 13.5 \mathrm{e} \\
(54.5-112.7)\end{array}$ \\
\hline High frequency $(\mathrm{Hz})$ & $\begin{array}{c}2089.9 \pm 329.3 \mathrm{a} \\
(1114.6-2964.9)\end{array}$ & $\begin{array}{c}1863.3 \pm 35.6 \mathrm{a} \\
(1775.7-1927.2)\end{array}$ & $\begin{array}{l}816.5 \pm 97.6 b c \\
(569.6-973.9)\end{array}$ & $\begin{array}{l}3668.0 \pm 725.9 .6 \mathrm{~d} \\
(2252.1-5577.7)\end{array}$ & $\begin{array}{c}924.5 \pm 98.0 b \\
(729.8-1178.8)\end{array}$ & $\begin{array}{c}332.0 \pm 25.8 \mathrm{c} \\
(281.2-421.5)\end{array}$ \\
\hline
\end{tabular}

The number of pulses is related to the duration of each individual sound (Fig 9A). The duration increased as the number of pulses increased. This is directly related to both pulse rate and pulse period. The pulse rate was higher in Chorus V and Chorus I: about 60 and 122 pulses per second, respectively. There was a correlation between dominant frequency and pulse period, and between dominant frequency and pulse rate for Choruses I, III, IV and V. The dominant frequency increased as the pulse period decreased (Fig. 9B) and pulse rate increased (Fig. 9C). This did not happen for Choruses II and IV. The Chorus IV sound, unlike the other four choruses, had fewer pulses and lasted approximately one second.

\section{DISCUSSION}

Marine soundscapes are composed of physical (e.g. waves), biological (e.g. fish) and anthropogenic components (e.g. ships). Fish sounds are typically clear at frequencies $<1 \mathrm{kHz}$ and the sound of benthic invertebrates is clear at $>1 \mathrm{kHz}$ (Kennedy et al. 2010). We determined here the soundscape of a marine protected area and of an unprotected area in northern Brazil. Snapping shrimp and six different choruses dominated the soundscape. The choruses ranged from 200 to $4000 \mathrm{~Hz}$ and were likely produced by aggregations of several fish and crustacean species.

Snapping shrimp is a ubiquitous sound source found in all oceans. Depending on the location, they have a varying diurnal snapping activity pattern. Radford et al (2008) found that snapping shrimp dominate the temperate soundscapes of New Zealand at dawn and dusk. In northeastern Brazil, snapping shrimp are more active at dusk and produce a characteristic snap sound of between 1 and $4 \mathrm{kHz}$, with a dominant frequency of between 2 and $3 \mathrm{kHz}$, although frequencies can reach $22050 \mathrm{~Hz}$ (our sampling limit). This sound was a constant cacophony during the day, but the highest intensity was at night. The "snap" signal has characteristics similar to those found in some marine invertebrates, particularly $\mathrm{Al}$ - pheus genera, which produce snapping sounds within a wide frequency band: between $\sim 1$ and $15 \mathrm{kHz}$ (Schmitz 2002; Coquereau et al. 2016). Snapping shrimp (family Alpheidae) produce the major component of reef noise at frequencies above $2 \mathrm{kHz}$. The highest intensities occur at the beginning and end of the night in Hawaiian reefs (Lammers and Munger 2016). Another important component of the soundscape is lobster sounds. Species of the genus Palunirus sp. can emit stridulating? sounds at frequencies of between 2 and $5.5 \mathrm{kHz}$ (Mulligan and Fischer 1977); the dominant frequency is between 3.7 and $5.2 \mathrm{kHz}$ (Latha et al. 2005). Kikuchi et al. (2015) suggested that the frequency of stridulating sounds possibly reflects the activity and presence of commercially important lobsters of the same genus.

The "Rap" sound found as an aggregation in Porto de Galinhas during sunset has similar characteristics to those of sounds produced by Ocypodidae (Brachyura). The frequencies are up to $2 \mathrm{kHz}$ (Horch 1975) and dominant frequencies are between 1.1 and $3.2 \mathrm{kHz}$ (Clayton 2001). Males of some Ocypodidae species produce a drumming sound by stridulating their claw during courtship (Mowles et al. 2017). Ocypodidae, Alpheidae and Palinuridae species can be commonly found in our study area, particularly in Porto de Galinhas (Giraldes et al. 2015), as well in other areas along the Pernambuco coast (Coelho et al. 2006, 2007, Barreto et al. 1993). They can contribute to the cacophony of crustaceans found in this study.

The six chorus types detected here have sound characteristics typically representative of fish. They were mainly detected during sunset and after midnight. Chorus III occurred only near the Ilha da Barra reef (MLPZ 1 and 2). It is commonly heard in the study area by divers (authors' personal observation). This Chorus showed a dominant frequency mean of $414 \mathrm{~Hz}$, which is similar to that of reproductive sounds found in many coral reef damselfish (Pomacentridae) (Mann and Lobel 1997, Maruska et al. 2007, Parmentier and Frederich 2016, Parmentier et al. 2009). 
The frequency bandwidth of the choruses varied. It was broad in Choruses I and IV and narrow in Choruses II and VI. Some choruses may therefore have different frequency band distributions and can show spatial and temporal overlapping (Pearson et al. 2016). Due to the absence of vision during the night, the communication sound plays a more important role (Ruppé et al. 2015). The lack of time and chorus frequency partitioning in hours of darkness illustrates the complexity of monitoring different communities of sound-producing fish (Parsons et al. 2016, in Australia).

Similar frequency band of choruses founded in this study have been found in fish detected in marine protected areas in southeastern sub-tropical regions of Brazil (Sánchez-Gendriz and Padovese 2016), although they are produced at different times of the day. There was no temporal competition between them, but rather a temporal overlaping observed during the early morning hours (Sánchez-Gendriz and Padovese 2017). This could indicate that fish species emitting this type of signal may have a wide distribution on the Brazilian coast, occurring in both tropical and temperate waters. The timing differences could be related to the migratory patterns of these species.

In this study we present evidence that the acoustic energy of Choruses II, IV, V and VI were higher after the last coastal reef line in Tamandaré. Several habi-
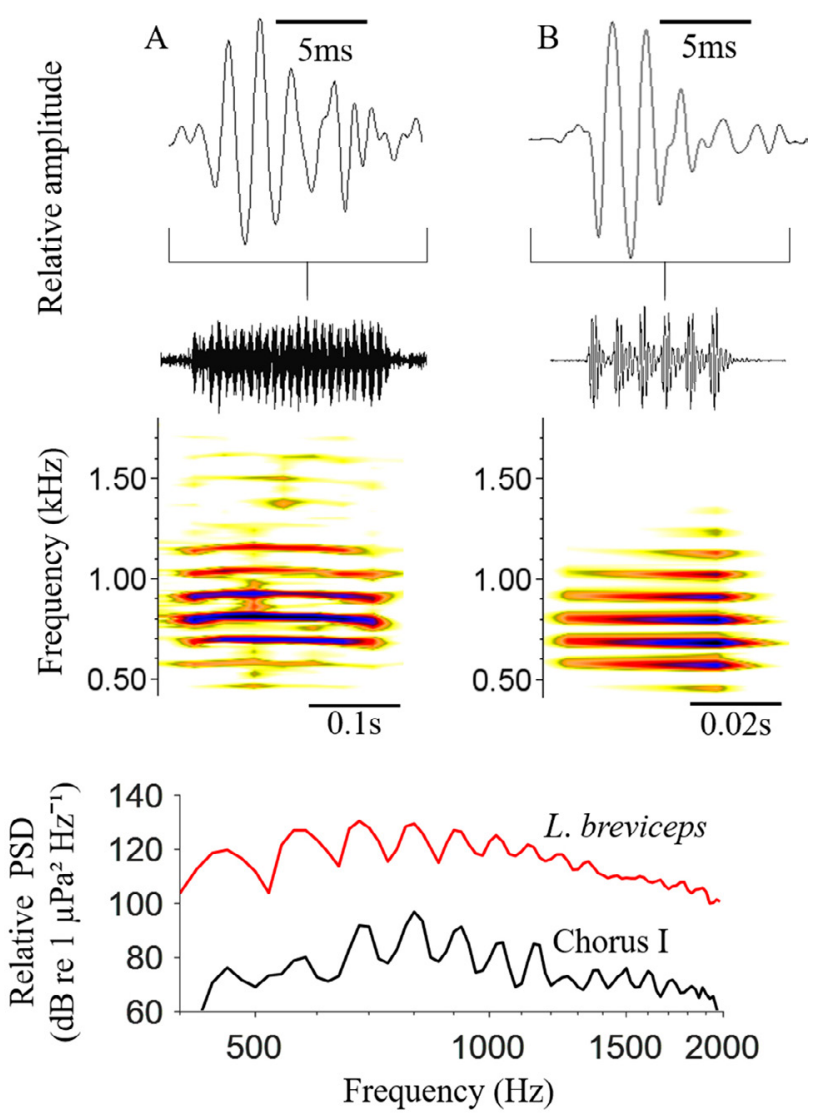

Fig. 10. - Individual call waveform, spectrogram and power spectra density of A, Chorus I; B, Larimus breviceps sound file recorded under stress by Fish and Mowbray (1970), available at http://www. fishbase.org/physiology/FishSoundsSummary.php?autoctr=149. tats showed significantly different energies. There was a decreasing level of energy from the reef towards the coast, showing that closely related habitats separated by $1 \mathrm{~km}$ may differ significantly (Bertucci et al. 2015). The imperceptive or low acoustic energy of crustaceans observed in MLPZ 4 and PGA 2 may be related to distance from the reef. Kaplan and Mooney (2016) indicated that the sound of the reef is of low intensity and may not reach distances greater than $1.5 \mathrm{~km}$.

The detection of fish choruses in this area may be associated with the type of substrate at these sites. On coastal reefs on the southern coast of Pernambuco it is possible to find a muddy substrate resulting from river depositions (Kempf 1970). Muddy patches are of commercial interest, as artisanal fishery target these areas for shrimp and fish, catching mainly sciaenids (Silva Júnior et al. 2015). Some of these species can also be found in Brazilian temperate waters (Schmidt and Dias 2012). The genera are widely distributed throughout the western Atlantic.

One of the most interesting and well-known aspects of the Scieanidae family is that they produce sounds and are commonly called "croakers". Several species of this family produce sounds during the reproductive season, particularly during the night (Lagardère and Mariani 2006, Luczkovich et al. 2008, Mok et al. 2009). Several studies on sciaenid sounds have been conducted in the northwest Atlantic. Field studies using passive acoustics monitored spawning activity of a resident aggregation of Cynoscion nebulosus over a long period (Walters et al. 2009). The critical spawning habitats of Cynoscion regalis, Bairdiella chrysoura and Sciaenops ocellatus have also been mapped (Luczkovich et al. 2008). In the southwest Atlantic, Micropogonias furnieri produces a characteristic seasonal and daily sound of courtship/spawning in the Rio de la Plata estuary from November to March (Tellechea et al. 2011). Larvae of Sciaenidae were highly abundant in areas near our study site (Junior et al. 2011), possibly indicating that the sounds we detected could have been made by species of the family Sciaenidae during the reproductive process.

A comparison of individual calls of Chorus I with those of Larimus breviceps found in the western Atlantic (Fish and Mowbray 1970) showed an acoustic similarity. The harmonic distribution of frequency bands occurred at peak intervals every $100 \mathrm{~Hz}$ (Fig. 10). L. breviceps is a widely distributed species with harmonious "hornlike" sounds and frequencies of between 500 and $1000 \mathrm{~Hz}$ (Ramcharitar et al. 2006).

Several species of the genus Cynoscion, widely distributed throughout the western Atlantic, are known to emit sounds during the reproductive period. Some species emit a wide range of dominant frequencies, from $\sim 347$ to $1046 \mathrm{~Hz}$ (Connaughton 1995, Sprague et al. 2000), particularly in the northwest Atlantic. $C$. gutupaca emits a dominant frequency of $450 \mathrm{~Hz}$ in the southwestern Atlantic (Tellechea and Norbis 2012). These differences in frequency could be caused by differences in swim bladder size, which is in turn correlated with fish size (Connaughton et al. 2000). The close relationship between Choruses I, V and VI may also be 
related to the sound mechanism. Sound production by these fish occurs through a pair of sonic muscles commonly found in males (Chao 1978).

The results show a soundscape composed of crustacean and fish choruses (dominant frequencies $<1 \mathrm{kHz}$ ). The choruses showed high energy after the last reef line in the protected area but low energy in unprotected areas. Higher levels of acoustic energy in the marine protected area may indicate the importance of these environments to fish populations. This information shows the importance and the usefulness of passive acoustics tools in monitoring and protecting coral reef biodiversity to guarantee sustainable fisheries and improve the management of populations. Greater efforts are still needed in order to improve the identification of the sound sources that compose the soundscape in these areas and in other marine ecosystems, with a potential for fast and non-intrusive biodiversity assessments.

\section{ACKNOWLEDGEMENTS}

This work was funded by the Brazilian National Council for Scientific and Technological Developmen, Call MCTI/CNPQ/Universal 14/2014, Process no. 459456/2014-8. The authors would like to thank everyone of the team of the Centro de Pesquisa e Conservação da Biodiversidade Marinha do Nordeste (CEPENE), especially for their suggestions on the manuscript.

\section{REFERENCES}

Amorim M.C.P. 2006. Diversity of sound production in fish. Communication in fishes. v. 1: 71-104.

Barradas J.I., Amaral F.M.D., Isabel, M., et al. 2010. Spatial distribution of benthic macroorganisms on reef flats at Porto de Galinhas Beach (northeastern Brazil), with special focus on corals and calcified hydroids. Biotemas 23: 61-67. https://doi.org/10.5007/2175-7925.2010v23n2p61

Barradas J.I., Amaral F.D., Hernández M.I., et al. 2012. Tourism impact on reef flats in Porto de Galinhas beach, Pernambuco, Brazil. Arq. Cienc. Mar. 45: 81-88.

Barreto A., Coelho P., Ramos-Porto M., et al. 1993. Distribuicão geográfica dos Brachyura (Crustacea, Decapoda) coletados na plataforma continental do Norte e Nordeste do Brasil. Rev. Bras. Zool. 10: 641-656. https://doi.org/10.1590/S0101-81751993000400010

Bertucci F., Parmentier E., Berten L., et al. 2015. Temporal and spatial comparisons of underwater sound signatures of different reef habitats in Moorea Island, French Polynesia. PLOS ONE 10: 1-12. https://doi.org/10.1371/journal.pone.0135733

Bertucci F., Parmentier E., Lecellier G., et al. 2016. Acoustic indices provide information on the status of coral reefs: an example from Moorea Island in the South Pacific. Sci. Rep. 6: 33326. https://doi.org/10.1038/srep33326

Boon P.Y., Yeo D.C.J., Todd P.A. 2009. Sound production and reception in mangrove crabs Perisesarma spp. (Brachyura: Sesarmidae). Aquat. Biol. 5: 107-116. https://doi.org/10.3354/ab00136

Buscaino G., Filiciotto F., Gristina M., et al. 2011. Acoustic behaviour of the European spiny lobster Palinurus elephas. Mar. Ecol. Prog. Ser. 441: 177-184. https://doi.org/10.3354/meps09404

Chao L. N. 1978. A basis for classifying Western Atlantic Sciaenidae (Teleostei: Perciformes). NOAA Tech. Rep. 415: 1-64

Charif R.A., Waack A.M., Strickman L.M. 2010. Raven Pro 1.4 User's Manual. Cornell Lab of Ornithology, Ithaca: NY.

Clayton D. 2001. Acoustic calling in four species of ghost crabs: Ocypode jousseaumei, $O$. platytarsus, $O$. rotundata and $O$. saratan (Brachyura: Ocypodidae). Bioacoustics 12: 37-55. https://doi.org/10.1080/09524622.2001.9753477
Coelho P.A., De Almeida A.O., De Souza-Filho J.F., et al. 2006. Diversity and distribution of the marine and estuarine shrimps (Dendrobranchiata, Stenopodidea and Caridea) from North and Northeast Brazil. Zootaxa 1221: 41-62. https://doi.org/10.11646/zootaxa.1221.1.5

Coelho P.A., Almeida A., Bezerra L., et al. 2007. An updated checklist of decapod crustaceans (infraorders Astacidea, Thalassinidea, Polychelida, Palinura, and Anomura) from the northern and northeastern Brazilian coast. Zootaxa 1519: 1-16. https://doi.org/10.11646/zootaxa.1519.1.1

Connaughton M.A., Taylor M.H. 1995. Seasonal and daily cycles in sound production associated with spawning in the weakfish, Cynoscion regalis. Environ. Biol. Fishes 42: 233-240. https://doi.org/10.1007/BF00004916

Connaughton M.A., Taylor M.H., Fine M.L. 2000. Effects of fish size and temperature on weakfish disturbance calls: implications for the mechanism of sound generation. J. Exp. Biol. 203: 1503-1512.

Coquereau L., Grall J., Chauvaud L., et al. 2016. Sound production and associated behaviours of benthic invertebrates from a coastal habitat in the north-east Atlantic. Mar. Biol. 163: $1-13$ https://doi.org/10.1007/s00227-016-2902-2

Dominguez J.M.L., Bittencourt A.C.D.S.P., Leão Z.M.D.A.N., et al. 2018. Geologia do Quaternário costeiro do estado de Pernambuco. Rev. Bras. Geocienc, 20: 208-215. https://doi.org/10.25249/0375-7536.1990208215

Eggleston D.B., Lillis A., Bohnenstiehl D.R. 2016. Soundscapes and Larval Settlement: Larval Bivalve Responses to Habitat-Associated Underwater Sounds. In: Popper A., Hawkins A. (eds) The Effects of Noise on Aquatic Life II. Adv. Exp. Med. Biol. 875: 255-263. https://doi.org/10.1007/978-1-4939-2981-8_30

Ferreira B.P., Cava F. 2001. Ictiofauna marinha da APA Costa dos Corais: Lista de espécies através de levantamento da pesca e observações subaquáticas. Bol. Técn. Cient. CEPENE, Tamandaré 9: 167-180.

Ferreira B.P. Maida M. 2006. Monitoramento dos recifes de coral do Brasil. Secretaria de Biodiversidade e Florestas, Brasília-DF, MMA, $120 \mathrm{pp}$.

Fish M.P. Mowbray W.H. 1970. Sounds of Western North Atlantic fishes: A reference file of biological underwater sounds. The John Hopkins Press, Baltimore. Rhode Island Univ. Kingston Narragansett Marine Lab.

Frankel A.S. 2009. Sound production. In: Perrin W.F., Wúrsig B. et al. (eds), Encyclopedia of marine mammals. (eds). Academic Press, London, pp. 1056-1071. https://doi.org/10.1016/B978-0-12-373553-9.00242-X

Giraldes B.W., Coelho Filho P.A., Smyth D.M. 2015. Decapod assemblages in subtidal and intertidal zones-Importance of scuba diving as a survey technique in tropical reefs, Brazil. Glob. Ecol. Conserv. 3: 163-175. https://doi.org/10.1016/j.gecco.2014.11.011

Harris S.A., Shears N.T., Radford C.A. 2016. Ecoacoustic indices as proxies for biodiversity on temperate reefs. Methods Ecol. Evol. 7: 713-724. https://doi.org/10.1111/2041-210X.12527

Horch K. 1975. The acoustic behavior of the ghost crab Ocypode cordimana Latreille, 1818 (Decapoda, Brachyura). Crustaceana 29: 193-205. https://doi.org/10.1163/156854075X00207

Junior J.L.B., Diaz X.G., Neumann-Leitão S. 2011. Diversidade de larvas de peixes das áreas internas e externas do porto de Suape (Pernambuco-Brazil). Trop. Oceanogr. Online 39: 1-13.

Kaplan M.B., Mooney T.A. 2016. Coral reef soundscapes may not be detectable far from the reef. Sci. Rep. 6: 1-10. https://doi.org/10.1038/srep31862

Kaplan M.B., Mooney T.A., Partan J., et al. 2015. Coral reef species assemblages are associated with ambient soundscapes. Mar. Ecol. Prog. Ser., 533: 93-107. https://doi.org/10.3354/meps11382

Kempf M. 1970. A plataforma continental de Pernambuco (Brasil): nota preliminar sobre a natureza do fundo. Trab. Oceanogr. Univ. Fed. PE, Recife 9: 111-124. https://doi.org/10.5914/tropocean. v9i1.2522

Kennedy E.V., Holderied M.W., Mair J.M., et al. 2010. Spatial patterns in reef-generated noise relate to habitats and communities: Evidence from a Panamanian case study. J. Exp. Mar. Bio. Ecol. 395: 85-92. https://doi.org/10.1016/j.jembe.2010.08.017 
Kikuchi M., Akamatsu T., Takase T. 2015. Passive acoustic monitoring of Japanese spiny lobster stridulating sounds. Fish. Sci. 81: 229-234. https://doi.org/10.1007/s12562-014-0835-6

Lagardère J.P., Mariani A. 2006. Spawning sounds in meagre Argyrosomus regius recorded in the Gironde estuary, France. J. Fish Biol. 69: 1697-1708. https://doi.org/10.1111/j.1095-8649.2006.01237.x

Lammers M.O. Munger L.M. 2016. From Shrimp to Whales: Biological Applications of Passive Acoustic Monitoring on a Remote Pacific Coral Reef. In: AU W., Lammers M. (eds), Listening in the Ocean. Modern Acoustics and Signal Processing. New York: NY. Springer, pp. 61-81. https://doi.org/10.1007/978-1-4939-3176-7 4

Lammers M.O., Brainard R.E., Au W.W., et al. 2008. An ecological acoustic recorder (EAR) for long-term monitoring of biological and anthropogenic sounds on coral reefs and other marine habitats. J. Acoust. Soc. Am. 123: 1720-1728. https://doi.org/10.1121/1.2836780

Latha G., Senthilvadivu S., Venkatesan R., et al. 2005. Sound of shallow and deep water lobsters: Measurements, analysis, and characterization (L). J. Acoust. Soc. Am. 117: 27202723 . https://doi.org/10.1121/1.1893525

Lillis A., Bohnenstiehl D.R., Eggleston D.B. 2015. Soundscape manipulation enhances larval recruitment of a reef-building mollusk. PeerJ. 3: e999. https://doi.org/10.7717/peerj.999

Lillis A., Bohnenstiehl D., Peters J.W., et al. 2016. Variation in habitat soundscape characteristics influences settlement of a reef-building coral. PeerJ. 4: e2557. https://doi.org/10.7717/peerj.2557

Lillis A., Apprill A., Suca J.J., et al. 2018. Soundscapes influence the settlement of the common Caribbean coral Porites astreoides irrespective of light conditions. R. Soc. Open Sci. 5: 181358. https://doi.org/10.1098/rsos.181358

Luczkovich J.J., Mann D.A., Rountree R.A. 2008. Passive Acoustics as a Tool in Fisheries Science. Trans. Am. Fish. Soc. 137: 533-541. https://doi.org/10.1577/T06-258.1

Mann D.A., Lobel P.S. 1997. Propagation of damselfish (Pomacentridae) courtship sounds. J. Acoust. Soc. Am. 101: 37833791 . https://doi.org/10.1121/1.418425

Maruska K.P., Boyle K.S., Dewan L.R., et al. 2007. Sound production and spectral hearing sensitivity in the Hawaiian sergeant damselfish, Abudefduf abdominalis. J. Exp. Biol. 210: 3990-4004. https://doi.org/10.1242/jeb.004390

Merchant N.D., Fristrup K.M., Johnson M.P., et al. 2015. Measuring acoustic habitats. Methods Ecol. Evol. 6: 257-265. https://doi.org/10.1111/2041-210X.12330

Mok H.K., Yu H.Y., Ueng J.P., et al. 2009. Characterization of sounds of the blackspotted croaker Protonibea diacanthus (Sciaenidae) and localization of its spawning sites in estuarine coastal waters of Taiwan. Zool. Stud. 48: 325-333.

Montgomery J.C., Jeffs A., Simpson S.D., et al. 2006. Sound as an orientation cue for the pelagic larvae of reef fishes and decapod crustaceans. Adv. Mar. Biol. 51: 143-196. https://doi.org/10.1016/S0065-2881(06)51003-X

Mowles S.L., Jennions M., Backwell P.R. 2017. Multimodal communication in courting fiddler crabs reveals male performance capacities. R. Soc. Open Sci. 4: 161093. https://doi.org/10.1098/rsos.161093

Mulligan B.; Fischer R. 1977. Sounds and behavior of the spiny lobster Panulirus argus (Latreille, 1804) (Decapoda, Palinuridae). Crustaceana 32: 185-199. https://doi.org/10.1163/156854077X00575

Parmentier E., Frederich B. 2016. Broadening of acoustic repertoire in Pomacentridae: tonal sounds in the Ambon damselfish Pomacentrus amboinensis. J. Zool. 300: 241-246. https://doi.org/10.1111/jzo.12382

Parmentier E., Lecchini D., Frederich B., et al. 2009. Sound production in four damselfish (Dascyllus) species: phyletic relationships? Biol. J. Linn. Soc., 97: 928-940. https://doi.org/10.1111/j.1095-8312.2009.01260.x
Parsons M.J.G., Salgado-Kent C.P., Marley S.A., et al. 2016. Characterizing diversity and variation in fish choruses in Darwin Harbour. ICES J. Mar. Sci. 73: 2058-2074. https://doi.org/10.1093/icesjms/fsw037

Piercy J.J., Codling E.A., Hill A.J., et al. 2014. Habitat quality affects sound production and likely distance of detection on coral reefs. Mar. Ecol. Prog. Ser. 516: 35-47. https://doi.org/10.3354/meps10986

Pijanowski B.C., Villanueva-Rivera L.J., Dumyahn S.L., et al. 2011. Soundscape Ecology: The Science of Sound in the Landscape. Bioscience 61: 203-216. https://doi.org/10.1525/bio.2011.61.3.6

Radford C., Jeffs A., Tindle C., et al. 2008. Resonating sea urchin skeletons create coastal choruses. Mar. Ecol. Prog. Ser. 362: 37-43. https://doi.org/10.3354/meps07444

Radford C.A., Stanley J.A., Simpson S.D., et al. 2011. Juvenile coral reef fish use sound to locate habitats. Coral Reefs 30: 295-305.

https://doi.org/10.1007/s00338-010-0710-6

Ramcharitar J., Gannon D.P., Popper A.N. 2006. Bioacoustics of Fishes of the Family Sciaenidae (Croakers and Drums). Trans. Am. Fish. Soc. 135: 1409-1431. https://doi.org/10.1577/T05-207.1

Rodríguez-Ramírez A., Bastidas C., Cortes J., et al. 2008. Status of coral reefs and associated ecosystems in southern tropical America: Brazil, Colombia, Costa Rica, Panamá and Venezuela. In: Status of coral reefs of the world, pp. 331-348.

Rountree R.A., Gilmore R.G., Goudey C.A., et al. 2006. Listening to fish: applications of passive acoustics to fisheries science. Fisheries, 31: 433-446. https://doi.org/10.1577/1548-8446(2006)31[433:LTF]2.0.CO;2

Ruppé L., Clément, G., Herrel A., et al. 2015. Environmental constraints drive the partitioning of the soundscape in fishes. Proc. Natl. Acad. Sci. 112: 6092-6097. https://doi.org/10.1073/pnas.1424667112

Sánchez-Gendriz, I., Padovese, L.R. 2016. Underwater soundscape of marine protected areas in the south Brazilian coast. Mar. Pollut. Bull. 105: 65-72. https://doi.org/10.1016/j.marpolbul.2016.02.055

Sánchez-Gendriz I., Padovese L.R. 2017. Temporal and spectral patterns of fish choruses in two protected areas in southern Atlantic. Ecol. Inform. 38: 31-38. https://doi.org/10.1016/j.ecoinf.2017.01.003

Schmidt T.C.D.S., Dias J.F. 2012. Pattern of distribution and environmental influences on the Scienidae community of the Southeastern Brazilian coast. Braz. J. Oceanogr. 60: 233243. https://doi.org/10.1590/S1679-87592012000200013

Schmitz B. 2002. Sound Production in Crustacea with Special Reference to the Alpheidae. Crustac. Nerv. Syst. 536-547. https://doi.org/10.1007/978-3-662-04843-6 40

Silva Júnior C.A.B., Viana A.P., Frédou F.L., et al. 2015. Aspects of the reproductive biology and characterization of Sciaenidae captured as bycatch in the prawn trawling in the northeastern Brazil. Acta Sci. Biol. Sci. 37: 1-8. https://doi.org/10.4025/actascibiolsci.v37i1.24962

Simpson S.D., Meekan M.G., McCauley R.D., et al. 2004. Attraction of settlement-stage coral reef fishes to reef noise. Mar. Ecol. Prog. Ser. 276: 263-268. https://doi.org/10.3354/meps276263

Sprague M.W., Luczkovich J.J., Pullinger R.C., et al. 2000. Using spectral analysis to identify drumming sounds of some North Carolina fishes in the family Sciaenidae. J. Elisha Mitchell Sci. Soc. 116: 124-145.

Tellechea J.S., Norbis W. 2012. Sexual dimorphism in sound production and call characteristics in the striped weakfish Cynoscion guatucupa. Zool. Stud. 51: 946-955.

Tellechea J.S., Bouvier D., Norbis, W. 2011. Spawning sounds in whitemouth croaker (sciaenidae): Seasonal and daily cycles. Bioacoustics 20: 159-168. https://doi.org/10.1080/09524622.2011.9753641

Walters S., Lowerre-Barbieri S., Bickford J., Mann D. 2009. Using a Passive Acoustic Survey to Identify Spotted Seatrout Spawning Sites and Associated Habitat in Tampa Bay, Florida. Trans. Am. Fish. Soc. 138: 88-98. https://doi.org/10.1577/T07-106.1 